\section{Some facts about Ye Shiwen's swim}

We write on behalf of the Chinese Biological Investigators Society, a professional organization of overseas and native Chinese scientists (www.cbisociety.org), to express our concern over your online News 'Explainer' about the performance of Ye Shiwen, a 16-year-old Chinese swimmer who won gold medals in the 200- and 400-metre individual medley during the London 2012 Olympics (http://doi.org/h55; 2012). We feel strongly that you overlooked some important facts.

You join in the widespread speculation that Ye's performance was anomalous, in which it has generally been implied that no one else has accomplished such a feat before without the aid of performanceenhancing drugs - a premise that, in our view, stems from data cherry-picked to support an unfounded accusation.

You indicate that Ye's 400metre performance was about 7 seconds faster than a time she set at a major meet a year earlier. Ye's personal best was actually set in 2010, when she was 14 years old. She improved her performance at the Olympics final by $5 \mathrm{~s}$ over her earlier personal best - a feat that is not anomalous, but is expected for elite swimmers of Ye's age as they grow bigger and stronger.

There are many examples of elite swimmers who showed a significant improvement at a young age. For example, Australian swimmer Ian Thorpe took $5 \mathrm{~s}$ off his 400 metre freestyle time between the ages of 15 and 16, and UK swimmer Adrian Moorhouse, Seoul Olympics gold medallist in 1988 , improved by $4 \mathrm{~s}$ in the 200-metre breaststroke aged 17 . The same happened to the other seven finalists in the 2012 Olympics women's 400-metre medley (see 'Young swimmers' improvements'). Also, Rūta Meilutytè, a 15-yearold Lithuanian swimmer,

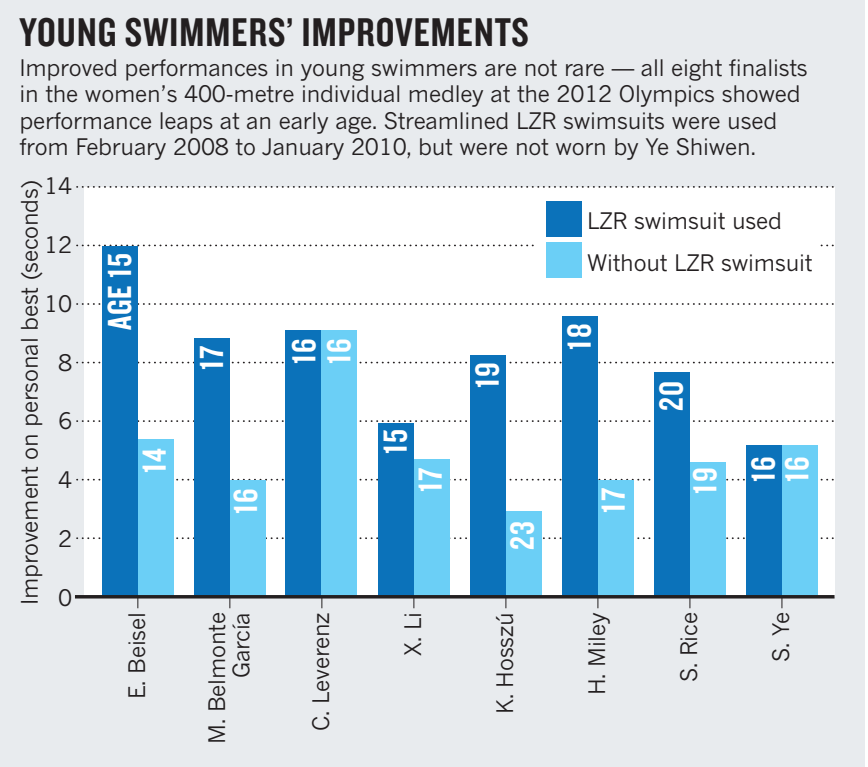

improved her personal best by more than $4 \%$ in the 100 -metre breaststroke, compared with Ye's improvement of $2 \%$ in the 400 metre medley.

You say that Ye "raised eyebrows" by her showing in the last 50 metres of the race, noting that she swam faster than US swimmer Ryan Lochte when he won gold in the men's 400-metre medley, the second-fastest time ever for that event. What you do not mention is that Ye was actually more than $23 \mathrm{~s}$ slower over 400 metres than Lochte, an eternity for elite swimmers at this distance.

In fact, the time for Lochte's last 50 metres is nowhere near the second-fastest ever for that event: several other swimmers in the same men's final were faster than he was and faster than Ye. Lochte ranked only fifth in the last 50 metres, at $29.1 \mathrm{~s}$, which was significantly slower than Japan's Yuya Horihata (27.87 s) and three other swimmers competing in the same event. Ye's time was $28.93 \mathrm{~s}$.

All of this information is available on the Internet. It is unfortunate that Nature seems to have put a stamp of scientific approval on the Western media's unsubstantiated speculation that Ye's feat is humanly impossible without the aid of performanceenhancing drugs.

We emphasize that our data serve only to provide a more complete backdrop to Ye's achievement, and not to negate her spectacular performance in winning two golds and shattering the world record.

Weimin Zhong Yale University, New Haven, Connecticut, USA. Hao Wu Children's Hospital Boston, Harvard Medical School, Boston, Massachusetts, USA. hao.wu@childrens.harvard.edu Linheng Li Stowers Institute for Medical Research, Kansas City, Missouri, USA.

\section{Stricter management of organ transplants}

Organ trafficking and the reported manipulation of data from patients on waiting lists (see A. Ginzel, M. Kraushaar and S. Winter Der Spiegel, 30 July 2012) are putting organ transplantation at risk by encouraging public distrust and threatening to reduce organ donation.

As former president of the European Group for Blood and Marrow Transplantation and of the foundation Swiss Blood Stem Cells, I suggest that haematopoietic stem-cell transplantation can offer lessons in stricter control of organ transplants and in promoting global cooperation.

The Worldwide Network for Blood and Marrow Transplantation (www.wbmt. org) has 20 million volunteer stem-cell donors, whose human leukocyte antigens (HLAs) have been typed to allow matching. Donors are selected only for matching with individual recipients and are protected and followed up according to standardized rules (J. P. Halter et al. Bone Marrow Transpl. http://doi.org/h54; 2012).

An accreditation system that ensures uniform quality of products and processes operates under identical regulations in Europe, the United States and Canada (see www.jacie.org and www.factwebsite.org), with health-care providers and payers increasingly demanding this accreditation as a condition for reimbursement. Internal and external audits of processes, together with standardized reporting to national and international data registries, are requisite.

Solid-organ transplantation would also benefit from a global quality-management system and from national networks of living HLA- and blood-typed volunteer donors. Although it will be hard to stamp out fraud altogether, professional oversight of activities would safeguard the interests of prospective donors and encourage more to register (A. Rios et al. Transplant Proc. 44, 1489-1492; 2012).

Alois Gratwohl University of Basel, Switzerland. alois.gratwohl@unibas.ch

\section{CONTRIBUTIONS}

Correspondence may be sent to correspondence@ nature.com after consulting the author guidelines at http://go.nature.com/ cmchno. 